Finanse, Rynki Finansowe, Ubezpieczenia nr 4/2016 (82), cz. 2

\title{
A Case Study of Intellectual Capital Management in a Polish Commercial Bank
}

\author{
Karolina Beyer*
}

\begin{abstract}
Purpose - The aim of the article is to present the results of conducted research in the field of intellectual capital management in a commercial bank operating on the Polish market.

Methodology - The audit of the intellectual capital in the examined Bank was conducted using an appropriate questionnaire form. The survey was supplemented with direct interviews with the chief management as well as with an analysis of internal documentation.

Findings - The result of the undertaken study is the cognition of the state of intellectual capital in the examined company as well as an indication of the postulated activities in the field of intellectual capital management.

Originality/value - Intellectual capital today is one of the most important assets in a company. The previous research undertaken by the author showed that intellectual capital in Polish enterprises was undervalued. That is why it was important to make an audit of intellectual capital where the results can be a base to formulate individual activities that may contribute to the increase in the value of intellectual capital and thus increase the value of the company.
\end{abstract}

Keywords: intellectual capital; intellectual capital management, commercial bank

\section{Introduction}

In recent years there has been increased interest in the field of intellectual capital management, especially among theorists. Unfortunately, as shown by previous studies of the Author (Beyer 2014), the interest of Polish business is not as intense as among foreign, especially Western companies. In today's economic reality the success of a business is dependent on the proper use of resources which distinguish one company from the competition. These resources should be unique, flexible and difficult to imitate by competitors. These kinds of features have an intangible nature and in a broader sense are defined as intellectual capital resources. It should be noted, however, that the intangible nature of intellectual capital makes the management of this category extremely difficult. Therefore, the first step in the process of intellectual capital management is to carry out an audit, which can primarily help to identify its components and to determine its condition.

This article presents a part of other broader studies including, among others, an analysis of intellectual capital in a commercial bank operating on the Polish market. Selecting the

\footnotetext{
* dr Karolina Beyer, Uniwersytet Szczeciński, Wydział Nauk Ekonomicznych i Zarządzania, e-mail: Karolina. Beyer@usz.edu.pl.
} 
bank organization to conduct an IC audit is justified by the previous findings, obtained by the Author in the process of measuring intellectual capital using indicators such as MV/ BV and VAIC. ${ }^{1}$ In the research conducted by the Author (Beyer 2013, 2014) the intellectual capital of banks listed on the Warsaw Stock Exchange, was characterized by a stable level in the considered period. In addition, the collapse of the stock exchange within the banking sector, which was the result of the global financial crisis in 2008 and 2011, did not have a negative impact on the level of intellectual capital measured with the MV/BV ratio. On average, banks listed on the Warsaw Stock Exchange had a market value of about twice higher than the book value. The difference between the two values indicates the existence of an intellectual capital, according to the concept of the MV/BV ratio. This research was an attempt at conducting a deeper analysis at one of the banks operating on the Polish market. The audit of intellectual capital in the entity aims to assess the actions taken in the field of management and the development of intellectual capital and its components.

\section{The issue of intellectual capital}

The concept of intellectual capital has no uniform definition. Often this term is referred to intellectual resources, intangible assets, etc. Intellectual capital can be defined as the "hidden" assets of companies that are not fully included in the financial reporting. According to L. Edvinsson intellectual capital includes knowledge, experience, technology, customer relationships, professional skills that enable organizations to achieve a competitive advantage in the market. In other words, intellectual capital is knowledge that can be transformed into value. Building an effective competitive advantage requires the proper management of intellectual capital and interactions between its elements. This can result in the increase of value. Elements of intellectual capital have a value, or may be the source of value in the future (Edvinsson, Malone 2001).

It is worth noting that the components of intellectual capital have not yet been uniformly defined. In the literature the structure of the intellectual capital consists for instance of: human capital, organizational capital and market capital. According to another classification intellectual capital includes: organizational/structural capital, human capital and relational capital, and yet, other sources divided intellectual capital into: social capital, organizational capital and human capital. In the above classifications, an element which does not arouse any doubt is human capital. In all concepts of intellectual capital, human capital is regarded as the most important component, so that other elements of intellectual capital may arise.

Therefore, what can be adopted is the structure of intellectual capital consisting of elements such as (Edvinsson, Malone 2001; Luthy; Stewart 1999; Łukasiewicz 2003):

- Human capital - an element integrated with a person, it includes, among others: knowledge, experience, skills, personal competences of employees,

\footnotetext{
${ }^{1}$ Value Added Intellectual Coefficient.
} 
- organizational capital - includes all elements that support the work of employees, among others: organizational structure, infrastructure, organizational culture, etc.,

- market capital - is the relationship with the external environment, mainly with customers but also with suppliers, competitors and partners. Market capital refers also to the reputation of the company and to customer loyalty.

The above structure of intellectual capital and the diversity of its components, indicates the complexity of the issues in question. The proper identification of the components of intellectual capital allows for a better understanding of its essence, and supports efforts to increase its potential. In addition, it should be emphasized that all the components of intellectual capital are closely interrelated, and its strength comes from the integration and interaction of its individual components. Therefore, the fundamental task of any enterprise should be an analysis of the intellectual capital resources.

\section{Intellectual capital in the examined commercial Bank}

The audited Bank is listed in the index WIG30 on the Warsaw Stock Exchange. The Bank is one of the commercial banks, and conducts its business on the Polish market. The entity offers a wide range of banking services to individual clients. The examined Bank conducts operations both in Polish zloty and in foreign currencies and actively participates in both domestic and foreign financial markets. In addition, through its subsidiaries, the holding company of the bank operates brokerage, leasing, factoring and provides other financial services. The bank has more than one thousand outlets across the country, as well as offering its clients access to a network of more than 5,500 free ATMs in Poland and about 20,000 in Europe. Within the bank's holding are also the largest Polish Investment Fund, Pension Fund, the two leading Polish brokerage houses, and companies engaged in the leasing and factoring services.

The bank employs about 17,000 employees, and more than half of them have higher education.

According to the conducted research it can be assumed that the concept of intellectual capital is known by the top-managers of the bank, who define it as:

a company's capital resulting from the knowledge of employees engaged in a constant process of the growth of the company's value ${ }^{2}$

Top managers of the audited bank claim that the intellectual capital consists of the following resources:

$$
\begin{aligned}
& \text { human capital - experience, know-how } \\
& \text { structural capital-brand, range }
\end{aligned}
$$

\footnotetext{
${ }^{2}$ Intellectual capital defined by the managers is associated primarily with the human capital omitting other, but important components of intellectual capital as: organizational capital and market capital.
} 
In the presented by top-managers definition of intellectual capital only human capital was included, while among components of intellectual capital the entity also indicated structural capital defined as a brand and range. It should be emphasized that, in accordance to the structure of intellectual capital adopted in this article, items such as brand and range should be included in the market capital.

Later in the conducted research the hierarchy of resources of the enterprise was analyzed. The results are presented in Table 1 .

\section{Table 1}

The hierarchy of the resources of the Bank

\begin{tabular}{ll}
\hline Position & Resources \\
\hline 1. & Human resources \\
2. & Financial resources \\
3. & Intangible assets \\
4. & Tangible assets \\
\hline
\end{tabular}

Source: own study based on the research results.

As the most important resource managers recognized human resources, followed by financial resources and intangible assets. The least important were considered tangible assets. The higher importance of financial resources against intangible assets is mainly due to the profile of the business. In the next step of the study managers were asked to create a hierarchy of competences of the company. The results are presented in Table 2.

\section{Table 2}

The hierarchy of the Bank's competences

\begin{tabular}{ll}
\hline Position & Resources \\
\hline 1. & Learning ability, skills broadening \\
2. & Human capital \\
3. & Know-how of the company \\
4. & Innovativeness \\
5. & Brand reputation \\
6. & Quality of products/services \\
7. & Internal processes \\
8. & Organizational culture \\
9. & Technical infrastructure \\
10. & Intellectual property \\
\hline
\end{tabular}

Source: own study based on the research results.

As the most important competences the bank recognized, those which are the carriers of knowledge and allow for its expansion, as human capital, know-how of the company as well as learning ability and the broadening of skills. As the less important competences the audited bank indicated the organizational culture, technical infrastructure and intellectual 
property. In the opinion of the author underestimating these competencies can be a barrier to the development of intellectual capital, because they constitute an important element in the creation of knowledge in the company.

The bank as one of the few among the surveyed entities, definitely confirms taking actions related to intellectual capital management and has for this purpose an appropriate organizational unit. The body responsible for the management of intellectual capital in the bank is the Human Resources Division. Unfortunately, the bank could not indicate whether it uses any method for the comprehensive management of intellectual capital, or not. In addition, the bank did not attempt to measure intellectual capital, even using the simplest methods and indicators.

\section{Human capital in the audited Bank}

The development of human capital can be assumed to be a positive. The bank undertakes a number of activities in this area. First of all, the bank identifies key staff and makes a competence hierarchy, which is presented in Table 3.

Table 3

The hierarchy of employee's competences

\begin{tabular}{ll}
\hline Position & Resources \\
\hline 1 & Possessed knowledge \\
2 & Ingenuity, creativity \\
3 & Motivation to work \\
4 & Education \\
5 & Experience \\
6 & Social skills \\
7 & Readiness to expand knowledge and skills \\
8 & Additional qualifications \\
9 & Team work ability \\
\hline
\end{tabular}

Source: own study based on the research results.

The most desirable competence of employees is possessed knowledge as well as competences associated with ingenuity and creativity, and motivation to work. Next, there was the education and experience of employees. The least important competence was recognized as being team work ability.

The most important competence possessed knowledge, is enriched, among others, through the process of training. The training in the audited entity is carried out about once a quarter. Unfortunately, the training is only carried out by employees within the enterprise. It should be noted, that the bank has a very wide variety of internal training sessions and is the only one of the surveyed enterprises which uses alternative forms of training, such as strategic games. In addition, the bank's employees are trained by: training in the workplace, 
being advised by experienced staff, coaching, e-learning and workers are encouraged to individual skills broadening.

The actions carried out within human capital management, are reflected in the effectiveness of the adopted incentive system, ${ }^{3}$ which according to the bank's opinion results in increased work efficiency. On the other hand, the audited bank cannot determine whether the lower-level employees have the opportunity to participate in the decision-making process of the company, or not.

What is important is that the adopted practice in the company HR policy encourages the exchange of knowledge and experience between employees. This encouragement process is carried out by encouraging discussions, exchange of views, and the development of informal collaboration between employees.

As a part of the activities in the field of human capital management, the bank also undertakes activities related to the creation of plans for the further development of employees and eliminating competency gaps, which are based on the results of the employee's evaluation.

Positively evaluated by the Author is that, the bank declares the measuring of the effectiveness of human capital.

It should be emphasized, that the HR policy used in the bank has also been repeatedly awarded by the Institute "Top Employers" certifying all over the world working conditions created by employers for their employees. ${ }^{4}$

\section{Organizational capital in the audited Bank}

The next phase of the research was associated with the assessment of activities in the field of organizational capital management. According to the opinions of the Top-managers of the Bank the organizational structure rather provides an efficient and rapid decision-making process. While, worrying is the response that the organizational culture of the Bank is rather not conducive to the exchange of knowledge and experience, which negatively testifies to the knowledge management process. It should be underlined, that the entity makes use of many tools for knowledge transfer such as the Internet, Intranet, e-mail, teleconferences, online discussions, communication systems, internal newsletters and instructions. In addition, the company defines a possessed infrastructure as modern. Therefore, it arouses astonishment, that the expanded knowledge management process is not reflected in the shape of an organizational culture.

In the field of licenses and other intellectual property rights the audited Bank is the buyer. As part of the major intangible assets the Bank indicates goodwill, copyrights and

\footnotetext{
${ }^{3}$ One of the basic incentive programs is grant stock options to employees. In addition, as part of the incentive system an employee may receive a premium, which consists of a portion paid in cash and the part granted in the form of phantom shares, as the cash equivalent of the value corresponding to the allocated shares. This system is dedicated to the most important employees and top-managers.

${ }^{4}$ More about the Institute "Top Employers" in the Internet resources: http://www.top-employers.com.
} 
software licenses. It should be emphasized, that the company also takes actions to protect its intellectual property rights.

Within the process of organizational capital management the Bank as one of the few makes attempts to measure the effectiveness of its use.

\section{Market capital of the audited Bank}

Among the field of the market capital, the audited bank takes high activity. First of all, it takes actions related to examine its reputation. The company examines its reputation carrying out their own research, as well as using the services of specialized entities; it also obtains information from external sources such as the media or gossip.

The audited bank has been undertaking lots of activities related to customer relationship management. The bank uses for this purpose complex methods such as CRM, Key Account Management, contacts management, loyalty programs for regular customers, Sales Force Automation, call center, complaint system and integration with ERP systems.

The effectiveness of customer relationship management is determined by examining customer feedback about the company and what it offers. For this purpose, customer satisfaction is examined through: own surveys of customer satisfaction, through mystery shopping, and obtained information about customer satisfaction from the environment (the media, gossip, etc.).

The bank also undertakes activities in the field of supplier relationship management. For this purpose, the company uses for instance: order processing systems, conducts an assessment of new contracts and suppliers, and periodically reviews the suppliers and contracts. In addition, the bank creates a policy of positive relationships with business partners. This is an important process, because the bank is expanding its operations through strategic alliances and other unique contracts, it performs the process of mergers and purchases licenses from business partners.

Despite the implementation of many activities to develop market capital the bank was unable to determine whether it measures the effectiveness of the use of its market capital, or not.

\section{Conclusions}

In this article the fragment of the audit of intellectual capital conducted in one of the banks operating on the Polish market was presented. The study presents the state of intellectual capital and its components (i.e., human capital, organizational capital and market capital) in the audited company.

The bank presented in this article takes a number of significant actions in the management of its intellectual capital. However, the Author suggests, that this process should be 
supported by the use of complex methods to manage its elements and the measurement of its value and efficiency.

The bank takes a broad activity in the field of human capital, organizational capital and market capital. The value added is that, the Bank measures the efficiency of human capital and organizational capital. Among the postulated direction of change, the Author encourages the executives of the Bank to try to manage the internal organizational culture by encouraging the exchange of knowledge and experience which can positively contribute to the growth of the effectiveness of the company.

In order to improve intellectual capital management the author recommends measuring the value and effectiveness of the use of its components. To increase the intellectual capital value it is recommended that actions are taken, so that the systematic human capital will be transformed into organizational capital, primarily through the transformation of the knowledge of employees into the organization's knowledge.

Postulates formulated in the article are only selected recommendations. The discussion in this article will be continued in further research by the Author in the future. As was indicated the importance of the issues of intellectual capital management in enterprises confirms the need for further verification of the proposed applications, as well as to observe the changes of the examined phenomenon in time.

The conducted study is a part of research on the intellectual capital of Polish companies. The results are the basis for the further research and analysis both of individual qualitative audits in companies and quantitative in terms of measuring their intellectual capital. The results of further work by the author will be presented in other scientific publications.

\section{References}

Beyer K. (2014). Kapital intelektualny przedsiębiorstw notowanych na GPW. Zeszyty Naukowe Uniwersytetu Szczecińskiego nr 804, Finanse, Rynki Finansowe, Ubezpieczenia nr 67.

Beyer K. (2014). Pomiar kapitału intelektualnego wskaźnikiem MV/BV. Zeszyty Naukowe Uniwersytetu Szczecińskiego nr 828, Studia i Prace WNEiZ nr 38, t. 1.

Beyer K. (2013). Pomiar kapitału intelektualnego wskaźnikiem VAIC TM. Zeszyty Naukowe Uniwersytetu Szczecińskiego 786, Finanse, Rynki Finansowe, Ubezpieczenia nr 64.

Edvinsson L., Malone M.S. (2001). Kapitat intelektualny. Warszawa: Wydawnictwo Naukowe PWN.

Luthy D.H. Intellectual Capital and its Measurement, http://www3.bus.osaka-cu.ac.jp/apira98/archives/pdfs/25.pdf.

Łukasiewicz G. (2003). Kapitat intelektualny organizacji-przeglad koncepcji i metod zarzadzania. Zeszyty Naukowe Akademii Ekonomicznej w Poznaniu, nr 36, Wydawnictwo AE w Poznaniu.

Stewart T.A. (1999). Intellectual Capital. The New Wealth of organizations. New York: Doubleday.

Top Employers Internet source: http://www.top-employers.com.

\section{STUDIUM PRZYPADKU - ZARZĄDZANIE KAPITAŁEM INTELEKTUALNYM W POLSKIM BANKU KOMERCYJNYM}

Streszczenie: $\mathrm{Cel}$ - Celem artykułu jest zaprezentowanie wyników przeprowadzonego badania w zakresie zarządzania kapitałem intelektualnym w banku komercyjnym działającym na rynku polskim.

Metodologia badania - Audyt kapitału intelektualnego w badanym banku przeprowadzono przy użyciu stosownego kwestionariusza ankietowego. Badanie uzupełnione zostało bezpośrednim wywiadem z naczelnym 
kierownictwem oraz analizą dokumentacji wewnętrznej.

Wynik - Efektem przeprowadzonych badań jest pozyskanie informacji na temat kondycji kapitału intelektualnego w badanym banku oraz wskazanie postulowanych działań w zakresie zarządzania kapitałem intelektualnym.

Oryginalność/wartość - Kapitał intelektualny współcześnie stanowi jeden z najważniejszych zasobów w przedsiębiorstwie. Wcześniejsze badania Autorki wykazały, iż kapitał intelektualny w praktyce polskich podmiotów gospodarczych jest niedowartościowany. Przeprowadzone badanie miało na celu dokonanie audytu kapitału intelektualnego, na podstawie którego w dalszej kolejności możliwe było sformułowanie indywidualnych działań, które mogą przyczynić się do wzrostu wartości kapitału intelektualnego, a tym samym do wzrostu wartości badanego przedsiębiorstwa.

Słowa kluczowe: kapitał intelektualny, zarządzanie kapitałem intelektualnym, bank komercyjny

\section{Citation}

Beyer K. (2016). A Case Study of Intellectual Capital Management in a Polish Commercial Bank. Finanse, Rynki Finansowe, Ubezpieczenia, 4 (82/2), 669-677. DOI: 10.18276/frfu.2016.4.82/2-58. 